\title{
Hubungan Mengonsumsi Makanan Selingan dengan Kejadian Early Childhood Caries pada Anak Usia 2-5 Tahun di Kota Padang
}

Retno Sri Mulyani ${ }^{1}$, Susi $^{1}$, Surma Adnan ${ }^{1}$

Korespondensi : Susi; susi@dent.unand.ac.id Telp: +628126752834

\begin{abstract}
Dental caries is one of the most common problem that can be found in both adults and children. Dental caries in primary teeth on children aged 0-71 months is known as Early Childhood Caries (ECC). Reports by Global Burden of Disease Study 2015 caries on primary teeth ranks 12th which affects as many as 560 million children worldwide. There are many predisposition factors that cause ECC, which are closely related to food consumption such as food snacking. The purpose of this study is to determine the relationship between food snacking consumption and Early Childhood Caries on children aged 2-5 years old in Padang. This study used a cross sectional design, with total sampel of 107 children aged 2-5 years in Padang. The location was selected through Stratified Random Sampling Method and samples was selected through Consecutive Sampling Method. Data was collected by using food frequency questionares and intra-oral examination that were analyzed by Chi-Square test with $p<0.05$. The results showed that there was a significant relationship between food snacking and ECC $(p=0.000)$. The conclution of this study was that food snacking consumption is associated with Early Childhood Caries on children aged 2-5 years in Padang.
\end{abstract}

Keywords: Early Childhood Caries, FFQ, food snacking

Affiliasi penulis : 1. Faculty of Dentistry, Universitas Andalas, Padang, Sumatera Barat.

PENDAHULUAN

Karies gigi merupakan masalah kesehatan yang paling sering terjadi di dunia, hampir setengah dari populasi dunia mengalami karies gigi sehingga menjadikan karies sebagai kondisi masalah kesehatan dengan prevalensi kejadian tertinggi. ${ }^{1}$ Setiap orang memiliki risiko untuk mengalami karies gigi, termasuk anak-anak maupun dewasa. ${ }^{2}$ Karies merupakan bentuk kerusakan jaringan gigi akibat demineralisasi yang disebabkan aktivitas perusakan oleh bakteri terhadap jaringan keras gigi yaitu email, dentin, dan sementum. ${ }^{3}$ Karies pada gigi desidui lebih sering terjadi dibandingkan gigi permanen disebabkan oleh struktur email pada gigi desidui yang kurang padat karena banyak mengandung air dan pola diet kariogenik yang tidak seimbang. ${ }^{4}$ Karies yang sering dijumpai pada anak dikenal dengan Early Childhood Caries (ECC). ${ }^{5}$ Karies pada anak dapat dimulai saat gigi erupsi, timbulnya karies juga mempunyai hubungan yang sangat erat dengan kebersihan rongga mulut dan pola makan anak. ${ }^{6}$

Prevalensi dan keparahan karies pada anak di beberapa negara masih tergolong tinggi. Berdasarkan 2015 Global Burden of Disease Study, karies pada gigi desidui menempati peringkat ke-12 yang mengenai sebanyak 560 juta anak di seluruh dunia. ${ }^{1}$ Riset kesehatan dasar (Riskesdas) tahun 2013 menyebutkan prevalensi yang bermasalah gigi dan mulut berdasarkan kelompok usia yaitu sebesar 10,4\% pada usia 1-4 tahun dan 28,9\% pada usia 5-9 tahun. ${ }^{7}$ Di Bukittinggi Sumatera Barat, prevalensi 
karies pada anak usia 2-3 tahun yaitu 51,5\% dengan indeks def-t rata-rata sebesar 2,33 yang tergolong dalam kategori rendah dengan total keseluruhan sampel sebanyak 66 orang. ${ }^{8}$

Berdasarkan American Academy of Pediatric Dentistry (AAPD) definisi dari Early Childhood Caries (ECC) adalah adanya satu atau lebih karies (kavitas atau non kavitas), gigi yang hilang karena karies, atau tambalan (filling) pada gigi desidui anak usia 0-71 bulan. ${ }^{9}$ ECC mempunyai karakteristik berupa perkembangan karies yang cepat pada sejumlah gigi anak segera setelah erupsi. ${ }^{10}$ ECC merupakan penyakit yang berhubungan dengan banyak faktor (multiple factors) yang merupakan hasil dari keterlibatan dari host, bakteri, substrat, dan waktu. Etiologi ECC juga dihubungkan dengan berbagai faktor risiko, salah satunya yaitu karena pemberian makanan selingan diluar waktu makan yang kurang tepat dan tidak tekontrol serta anak yang cenderung menyukai makanan selingan dibanding makanan utamanya. ${ }^{10,11}$

Penelitian yang dilakukan oleh Johansson et al di Boston Medical Center, Boston University and the Floating Hospital danTufts Medical Center Boston USA tahun 2009 pada anak usia 1-4 tahun dengan sampel sebanyak 1.206 anak,menyatakan bahwa hampir seluruh anak $(97 \%)$ dilaporkan mengonsumsi makanan selingan hampir setiap harinya dengan indeks def-t rata-rata 1.67 dengan kategori rendah, dimana sangat erat kaitannya dengan kejadian karies. ${ }^{12}$ Makanan selingan adalah jenis makanan yang sering dikonsumsi di luar waktu makan utama dapat berupa makanan ringan, camilan atau kudapan, dan aneka jajanan pasar. Makanan selingan berupa makanan jajanan memiliki daya tarik tersendiri bagi masyarakat. Makanan selingan berupa jajanan sering memiliki peran dalam menyebabkan penyakit gigi dan mulut terutama pada anak di bawah usia 12 tahun. Anak-anak menyukai jajanan karena umumnya mengandung gula yang sifatnya manis. Hal ini menyebabkan kebersihan gigi anak cenderung lebih buruk dibanding orang dewasa ditambah lagi anak-anak kurang menjaga kebersihan gigi dan mulut dalam hal membersihkan giginya. ${ }^{13,14,15}$

Rutin mengonsumsi makanan selingan berupa permen, biskuit, kue, minuman buah, soda, madu, makanan pabrik seperti keripik kentang, pasta, kerupuk dan sereal manis beberapa kali dalam sehari dapat meningkatkan risiko terjadinya karies karena makanan selingan terutama yang tergolong kariogenik berperan dalam menyebabkan penyakit gigi dan mulut. Sisa makanan di permukaan gigi yang tidak segera dibersihkan merupakan penyebab utamanya. Penelitian yang dilakukan oleh Iftikhar et al, membuktikan bahwa ditemukan adanya pengaruh anak dengan pola makan yang buruk berupa makanan selingan yang tidak tepat memiliki kemungkinan lebih besar mengalami karies dibandingkan anak yang tidak memiliki kebiasaan mengonsumsi makanan selingan. ${ }^{13,16}$

Usia 2-5 tahun merupakan usia dimana proses pertumbuhan dan perkembangan anak terjadi sangat cepat, oleh karena itu pola asuh orang tua sangatlah berperan penting dalam memenuhi asupan nutrisi anak melalui pengaturan pola makan. Pada masa ini, terjadi transisi dalam pemilihan makanan dan perubahan pola makan anak dari jenis makanan lunak ke padat, karena pada usia 2-5 tahun anak mulai mampu memilih makanan dan minuman yang disukainya. ${ }^{17,18}$ Di usia 2-5 tahun ini juga pada umumnya seluruh gigi desidui anak yang berjumlah 20 telah erupsi semua. ${ }^{19}$ Berdasasrkan data diatas, penulis tertarik untuk menganalisis hubungan makanan selingan terhadap kejadian ECC pada anak usia 2-5 tahun di Kota Padang. 


\section{METODE}

Penelitian ini merupakan penelitian analitik observasional dengan studi kasus Cross Sectional. Penelitian ini dilaksanakan pada bulan April-Mei 2019. Tempat penelitian ditentukan dengan metode Stratified Random Sampling yaitu di Posyandu Kelurahan Gunung Pangilun, Kecamatan Padang Utara dan Posyandu Kelurahan Piai Tanah Sirah Kecamatan Lubuk Begalung Kota Padang. Sampel penelitian ini adalah anak usia 2-5 tahun di posyandu Kelurahan Piai Tanah Sirah dan Lubuk Begalung Kota Padang beserta orang tuanya yang berjumlah 107 orang yang sudah memenuhi kriteria inklusi penelitian. Pemilihan sampel dilakukan dengan menggunakan teknik Consecutive Sampling. Penliaian karies dilakukan dengan cara pemeriksaan gigi pada sampel dengan mengisi lembar odontogram dengan menggunakan indeks def-t berdasarkan WHO. Konsumsi makanan selingan sampel di dapatkan dengan cara mewawancarai orang tua sampel menggunakan kuesioner Food Frequency Questionnaire (FFQ). Kuesioner FFQ terdiri dari 30 jenis makanan dan minuman dengan kategori kariogenik dan non kariogenik, untuk frekuensi konsumsi yaitu dalam 1 hari dan 1 minggu. Data hasil penelitian kemudian dilakukan analisis statistik menggunakan SPSS yaitu dengan chi-square.

\section{HASIL DAN PEMBAHASAN}

Hasil karakteristik responden berdarkan jenis kelamin dan usia dapat dilihat pada Tabel 1.

Tabel 1. Distribusi karakteristik responden berdasarkan jenis kelamindan usia 2-5 tahun di Kota Padang

\begin{tabular}{lcc}
\hline \multicolumn{1}{c}{ Karakteristik } & $\mathbf{n}$ & $\%$ \\
\hline JenisKelamin & & \\
Laki-laki & 53 & 49,5 \\
Perempuan & 54 & 50,5 \\
\hline Usia & & \\
2 tahun & 32 & 29,9 \\
3 tahun & 27 & 25,2 \\
4 tahun & 30 & 28 \\
5 tahun & 18 & 16,8 \\
\hline
\end{tabular}

Distribusi responden berdasarkan jenis kelamin terdapat jumlah responden perempuan lebih banyak dari pada responden laki-laki. Distribusi responden berdasarkan usia terdapat lebih banyak responden dengan usia 2 tahun. Gambaran kejadian Early Childhood Caries (ECC) pada anak usia 2-5 tahun di Kota Padang sebesar 3,86 dengan SD 3,541

Tabel 2. Indeks def-t berdasarkan wilayah tempat tinggal pada anak usia 2-5 tahun di Kota Padang

\begin{tabular}{lcc}
\hline \multicolumn{1}{c}{ Kelurahan } & n & Rerata def-t \\
\hline Gunung Pangilun & 58 & 3,93 \\
Piai Tanah Sirah & 49 & 3,78 \\
\hline Kota Padang & 107 & 3,86 \\
\hline
\end{tabular}


ANDalas deNtal journal

Fakultas Kedokteran Gigi Universitas Andalas

Jalan Perintis Kemerdekaan No. 77 Padang, Sumatera Barat

Web: adj.fkg.unand.ac.id Email: adj@dent.unand.ac.id

Tabel 3. Distribusi responden berdasarkan tingkat karies pada anak usia 2-5 tahun di Kota Padang

\begin{tabular}{lcc}
\hline \multicolumn{1}{c}{ Kategori def-t } & $\mathbf{n}$ & $\%$ \\
\hline Rendah & 44 & 41,1 \\
Sedang & 24 & 22,4 \\
Tinggi & 39 & 36,4 \\
\hline Jumlah & 107 & 100 \\
\hline
\end{tabular}

Nilai rata-rata def-t yaitu diperoleh sebesar 3,86 dengan hasil estimasi interval dapat disimpulkan bahwa 95\% diyakini bahwa rata-rata indeks def-t anak usia 2-5 tahun adalah diantara 3,18 sampai dengan 4,54. Rata-rata indeks def-t tertinggi terdapat pada wilayah kelurahan Gunung Pangilun sebesar 3,93 . dengan tingkat karies terbanyak pada kategori rendah yaitu sebanyak $41,4 \%$. Prevalensi ECC pada anak usia 2-5 tahun di Kota Padang sebesar 58,9\% sedangkan berdasarkan wilayah tempat tinggal prevalensi tertinggi berada pada Kelurahan Gunung Pangilun yaitu $60,3 \%$.

Tabel 4. Prevalensi Early Childhood Caries (ECC) pada anak usia 2-5 tahun di Kota Padang bulan AprilMei 2019

\begin{tabular}{lc}
\hline \multicolumn{1}{c}{ Wilayah } & Prevalensi (\%) \\
\hline Kelurahan Gunung Pangilun & 60,3 \\
Kelurahan Piai Tanah Sirah & 57,1 \\
Kota Padang & 58,9 \\
\hline
\end{tabular}

Jenis dan frekuensi konsumsi makanan dan minuman selingan berdasarkan kategori kariogenik dan non kariogenik dapat dilihat pada gambar 1,2, dan 3. Berdasarkan gambar 1 terlihat responden lebih banyak mengonsumsi makanan seperti kuaci, keju dan popcorn tanpa gula 0-1 kali dalam sehari.

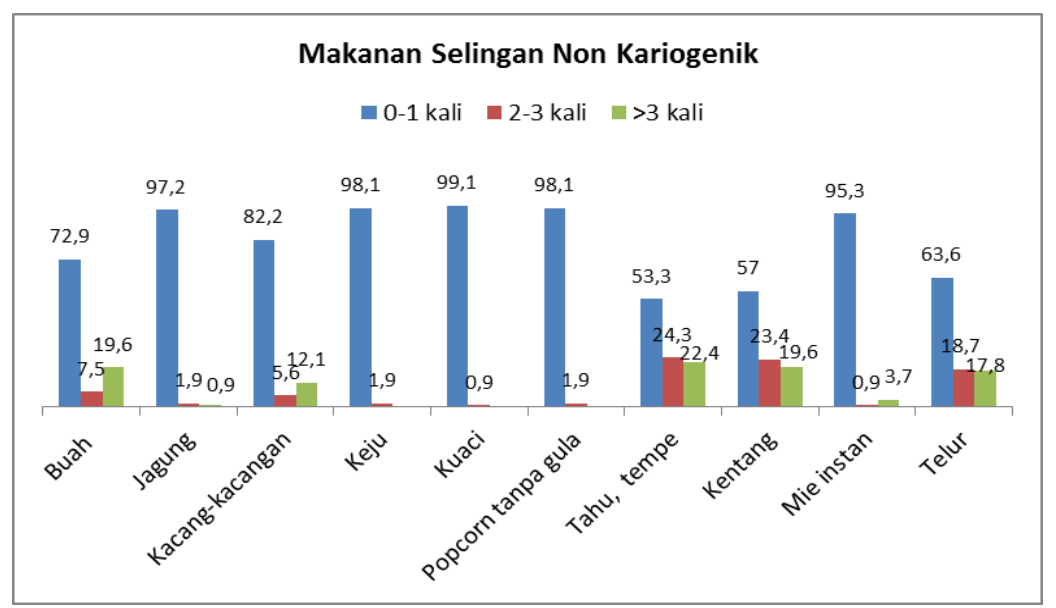

Gambar 1. Frekuensi responden berdasarkan jenis konsumsi makanan selingan non kariogenik per hari pada anak usia 2-5 tahun di Kota Padang 
ANDalas deNtal journal

Fakultas Kedokteran Gigi Universitas Andalas

Jalan Perintis Kemerdekaan No. 77 Padang, Sumatera Barat

Web: adj.fkg.unand.ac.id Email: adj@dent.unand.ac.id

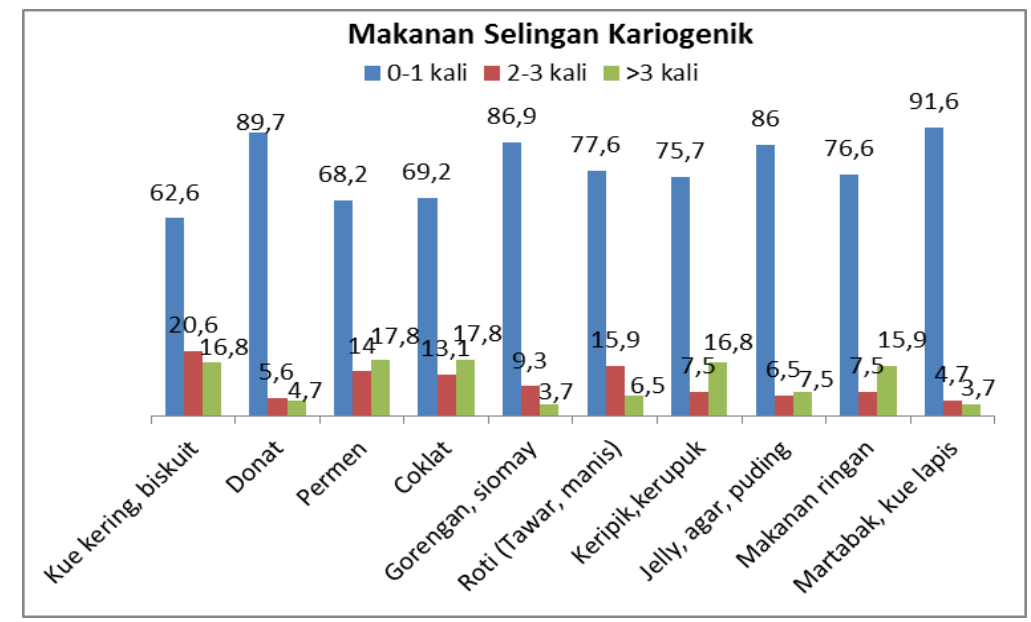

Gambar 2. Frekuensi responden berdasarkan jenis konsumsi makanan selingan kariogenik per hari pada anak usia 2-5 tahun di Kota Padang

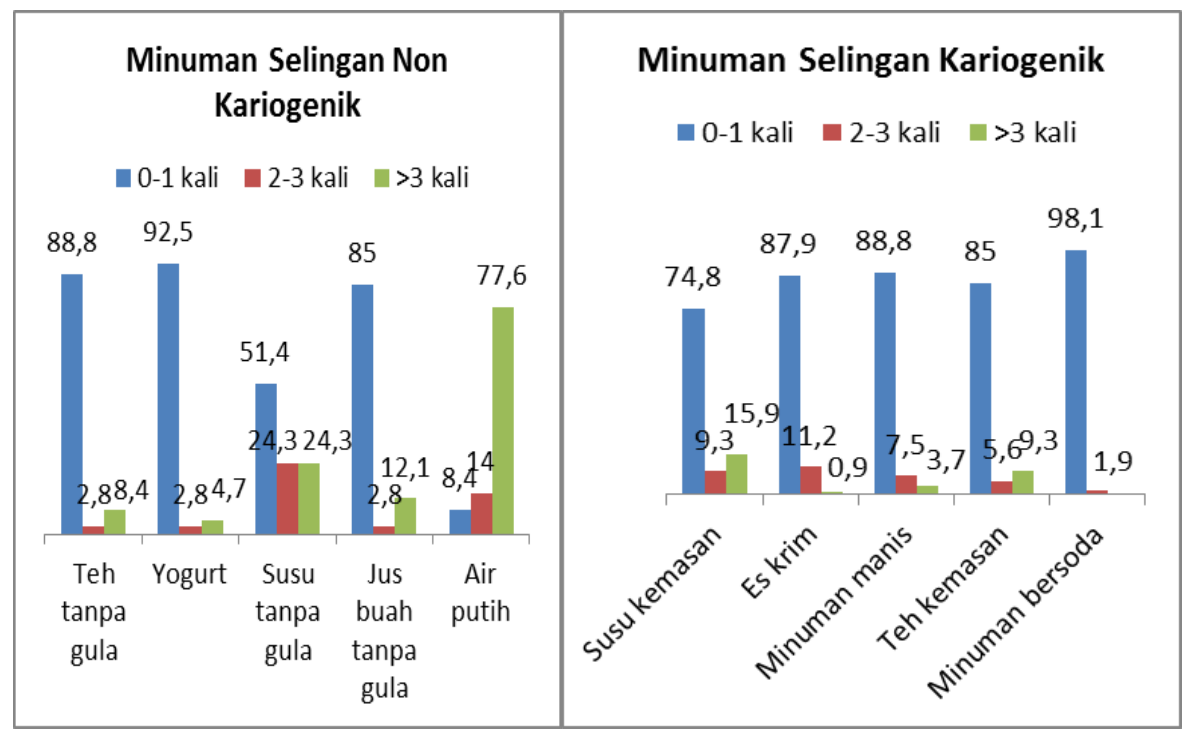

Gambar 3. Frekuensi responden berdasarkan jenis konsumsi minuman selingan non kariogenik dan kariogenik per hari pada anak usia 2-5 tahun di Kota Padang bulan April-Mei 2019

Berdasarkan gambar 2 terlihat responden lebih banyak mengonsumsi makanan seperti martabak, kue lapis, donat, gorengan dan siomay 0-1 kali dalam sehari. Gambar 3 menunjukkan distribusi responden berdasarkan jenis konsumsi minuman selingan non kariogenik per hari didapatkan responden lebih banyak mengonsumsi air putih $>3$ kali dalam sehari serta minuman seperti yogurt dan teh tanpa gula 0-1 kali dalam sehari. Minuman selingan kariogenik per hari didapatkan responden lebih banyak mengonsumsi minuman bersoda, minuman manis dan es krim 0-1 kali dalam sehari. Hail penelitian menunjukkan distribusi responden berdasarkan kriteria konsumsi makanan selingan lebih banyak dijumpai pada responden dengan kriteria konsumsi makanan selingan baik sebanyak $69,2 \%$ dan buruk sebanyak $30,8 \%$ 
Fakultas Kedokteran Gigi Universitas Andalas

Jalan Perintis Kemerdekaan No. 77 Padang, Sumatera Barat

Web: adj.fkg.unand.ac.id Email: adj@dent.unand.ac.id

Tabel 5. Distribusi responden berdasarkan kriteria konsumsi makanan selingan masing-masinng wilayah Kelurahan pada anak usia 2-5 tahun di Kota Padang bulan April-Mei 2019

\begin{tabular}{|c|c|c|c|c|c|c|}
\hline \multirow{3}{*}{ Wilayah Kelurahan } & \multicolumn{4}{|c|}{$\begin{array}{l}\text { Kriteria konsumsi makanan } \\
\text { selingan }\end{array}$} & \multirow{2}{*}{\multicolumn{2}{|c|}{ Total }} \\
\hline & \multicolumn{2}{|c|}{ Baik } & \multicolumn{2}{|c|}{ Buruk } & & \\
\hline & $\mathrm{n}$ & $\%$ & $\mathrm{n}$ & $\%$ & $\mathrm{n}$ & $\%$ \\
\hline Gunung Pangilun & 43 & 40,2 & 15 & 14 & 58 & 54,2 \\
\hline Piai Tanah Sirah & 31 & 29 & 18 & 16,8 & 49 & 45,8 \\
\hline Jumlah & 74 & 69,2 & 33 & 30,8 & 107 & 100 \\
\hline
\end{tabular}

Berdasarkan tabel 5 distribusi responden berdasarkan kriteria konsumsi makanan selingan berdasarkan masing-masing wilayah kelurahan didapatkan kriteria konsumsi paling banyak di Kelurahan Gunung Pangilun dan Kelurahan Piai Tanah Sirah yaitu baik. Hasil analisis hubungan makanan selingan dengan Early Childhood Caries (ECC) dengan menggunakan analisa statistik chi-square disajikan dalam tabel 6.

Tabel 6. Hubungan mengonsumsi makanan selingan dengan Early Childhood Caries (ECC) pada anak usia 2-5 tahun di Kota Padang bulan April-Mei 2019

\begin{tabular}{|c|c|c|c|c|c|c|c|c|c|}
\hline \multirow{3}{*}{$\begin{array}{c}\text { Kriteria } \\
\text { konsumsi } \\
\text { makanan } \\
\text { selingan }\end{array}$} & \multicolumn{6}{|c|}{ Status ECC } & \multirow{2}{*}{\multicolumn{2}{|c|}{ Total }} & \multirow{3}{*}{$P$ value } \\
\hline & \multicolumn{2}{|c|}{ Rendah } & \multicolumn{2}{|c|}{ Sedang } & \multicolumn{2}{|c|}{ Tinggi } & & & \\
\hline & $\mathbf{n}$ & $\%$ & $\mathbf{n}$ & $\%$ & $\mathbf{n}$ & $\%$ & $\mathbf{n}$ & $\%$ & \\
\hline Baik & 41 & 38,3 & 16 & 15 & 17 & 15,9 & 74 & 69,2 & \\
\hline Buruk & 3 & 2,8 & 8 & 7,5 & 22 & 20,6 & 33 & 30,8 & 0,000 \\
\hline Jumlah & 44 & 41,1 & 24 & 22,4 & 39 & 36,4 & 107 & 100 & \\
\hline
\end{tabular}

Berdasarkan analisis data diketahui terdapat hubungan antara mengonsumsi makanan selingan terhadap kejadian Early Childhood Caries (ECC) dengan nilai P 0,000. Status kejadian ECC paling banyak terjadi yaitu kategori rendah dengan kriteria konsumsi makanan selingan baik.Inde ks rata-rata def-t pada anak usia 2-5 tahun di Kota Padang diperoleh sebesar 3,86 yang berarti setiap anak rata-rata memiliki 3 lebih gigi yang mengalami karies. Hal ini terjadi dapat dikaitkan dengan karakteristik responden yang masih tergolong anak usia prasekolah dimana diketahui anak dengan usia prasekolah rentan terhadap penyakit gigi dan mulut karena masih tergantung pada pengetahuan, kesadaran dan perilaku orang tua disebabkan anak masih mempunyai perilaku atau kebiasaan diri yang tidak menunjang terhadap kesehatan gigi. ${ }^{20} \mathrm{Hasil}$ penelitian ini sejalan dengan penelitian yang dilakukan oleh Winda et al (2015) pada anak usia 3-5 tahun di PAUD desa Pineleng II Indah di dapatkan indeks rata-rata def-t sebesar 4,3 yang berdasarkan kriteria WHO termasuk kategori karies sedang. ${ }^{19}$

Wilayah Kelurahan Gunung Pangilun memiliki indeks def-t sedikit lebih tinggi yaitu 3,93 dengan prevalensi kejadian karies 60,3\% dibandingkan wilayah Kelurahan Piai Tanah Sirah dengan indeks def-t sebesar 3,78 dan prevalensi kejadian karies 57,1\% dimana terdapat perbedaan yang tidak begitu signifikan. Lebih tingginya indeks def-t pada wilayah dengan kepadatan penduduk tinggi sesuai dengan penelitian yang dilakukan oleh Phyo et al tahun 2013 di Yangon Myanmar yang menyebutkan indeks karies di daerah urban atau perkotaan lebih tinggi dari pada daerah rural atau pedesaan. Hal ini 
disebabkan karena makanan ringan dengan kandungan gula yang lebih tinggi lebih mudah didapatkan di daerah perkotaan sehingga konsumsi gula di daerah perkotaan lebih tinggi dari pada daerah pedesaan yang menyebabkan gigi lebih mudah terserang karies. ${ }^{21}$ Berdasarkan hasil estimasi interval derajat kepercayaan dapat disimpulkan 95\% diyakini bahwa rata-rata indeks def-t responden di kedua wilayah tersebut adalah 3,18 sampai dengan 4,54.

Prevalensi kejadian ECC pada anak usia 2-5 tahun di Kota Padang berdasarkan hasil penelitian didapatkan sebesar 58,9\%. Hal ini dapat disebabkan karena kebiasaan anak-anak yang gemar mengonsumsi makanan dan minuman manis dikarenakan ketidakmampuan orang tua dalam melakukan pencegahan primer seperti pengaturan pola makan anak yang diketahui menjadi permasalahan utama atas terjadinya karies. ${ }^{22}$ Berdasarkan penelitian yang telah dilakukan menunjukkan status ECC yang paling banyak ditemukan adalah karies dengan kategori rendah yaitu sebanyak $41,1 \%$. Banyaknya responden dengan status karies rendah dapat disebabkan karena peran dari orang tua terutama ibu dalam hal pengetahuan dan perilaku dalam menerapkan pemeliharaan kesehatan gigi dan mulut yang benar serta dapat mengontrol pola konsumsi yang baik untuk anak dengan cara tidak mengenalkan makanan dan minuman kariogenik pada anak sedari usia dini. ${ }^{17}$

Berdasarkan hasil penelitian menunjukkan bahwa sebanyak $69,2 \%$ responden dengan kriteria konsumsi makanan selingan baik. Tingginya kriteria konsumsi yang baik disebabkan karena pola asuh orang tua dalam pengaturan pola konsumsi yang benar dalam pemilihan makanan dan minuman yang baik untuk kesehatan gigi dan mulut anak. Konsumsi makanan non kariogenik dengan persentase konsumsi paling besar yaitu sebesar 99,1\% responden mengonsumsi kuaci 0-1 kali dalam sehari, 98,1\% responden mengonsumsi keju dan popcorn tanpa gula 0-1 kali dalam sehari serta 97,2\% responden mengonsumsi jagung 0-1 kali dalam sehari. Tingginya jenis konsumsi makanan non kariogenik ini dikarenakan makanan tersebut memiliki dampak untuk kesehatan yang baik serta sangat mudah diperoleh dilingkungan sekitar rumah. Konsumsi minuman non kariogenik dengan persentase konsumsi paling besar berdasarkan penelitian ini yaitu sebesar $77,6 \%$ responden mengonsumsi air putih $>3$ kali dalam sehari, 92,5\% responden mengonsumsi yogurt 0-1 kali dalam sehari dan $88,8 \%$ mengonsumsi teh tanpa gula 0-1 kali dalam sehari. Tingginya konsumsi air putih disebabkan karena air merupakan komponen utama dari tubuh manusia dimana sekitar $80 \%$ kebutuhan individu merupakan kontribusi dari cairan termasuk air putih dan sisanya diperoleh dari makanan. ${ }^{23}$

Hasil penelitian menunjukkan bahwa sebanyak 30,8\% responden dengan kriteria konsumsi makanan selingan buruk. Hal ini dapat disebabkan karena kurangnya pengetahuan orang tua mengenai makanan dan minuman yang baik untuk kesehatan gigi anak. Pengawasan orang tua yang kurang terhadap makanan yang dikonsumsi anak menyebabkan anak memilih makanan dan minuman yang lebih disukainya tanpa memperhatikan dampak buruk untuk kesehatan gigi dan mulut. ${ }^{17,18}$

Konsumsi makanan dan minuman selingan kariogenik dengan persentase konsumsi paling besar yaitu terdapat $91,6 \%$ responden mengonsumsi martabak dan kue lapis $0-1$ kali dalam sehari, $89,7 \%$ responden mengonsumsi donat $0-1$ kali dalam sehari, 86,9\% responden mengonsumsi gorengan dan siomay 0-1 kali dalam sehari, 98,1\% responden mengonsumsi minuman bersoda $0-1$ kali dalam sehari, $88,8 \%$ responden mengonsumsi minuman manis seperti pop ice dan jus buah dengan gula $0-1$ kali dalam 
sehari dan $87,9 \%$ responden mengonsumsi es krim 0-1 kali dalam sehari, tetapi ada beberapa responden yang mengonsumsi permen sebanyak $17,8 \%>3$ kali dalam sehari, coklat sebanyak 17,8\% >3 kali dalam sehari, keripik dan kerupuk sebanyak 16,8\% >3 kali dalam sehari serta susu kemasan sebanyak 15,9>3 kali dalam sehari. Hal ini terjadi dikarenakan makanan dan minuman tersebut sangat mudah didapatkan dilingkungan sekitar rumah dan juga harga yang sangat ekonomis sehingga konsumsi anak lebih cenderung mengonsumsi makanan dan minuman yang manis. Sesuai dengan penelitian yang dilakukan Worotijan et al (2013) dan Budisuari et al (2010) yang menyatakan sebanyak 60\% anak diketahui mengonsumsi makanan kariogenik dengan jenis makanan yang paling sering dikonsumsi anak yaitu permen, es krim, coklat, minuman manis dan biskuit manis dengan frekuensi konsumsi yaitu $\geq 4$ kali dalam 7 hari. 24,25

Kriteria konsumsi makanan selingan untuk masing-masing wilayah berdasarkan hasil penelitian didapatkan kriteria konsumsi makanan selingan paling banyak di Kelurahan Gunung Pangilun yaitu baik sebesar 40,2\% responden dan untuk Kelurahan Piai Tanah Sirah yaitu baik sebesar 29\% responden. Hal ini menunjukkan tidak adanya perbedaan kriteria konsumsi makanan selingan di wilayah dengan kepadatan penduduk tinggi dan wilayah dengan kepadatan penduduk rendah, hal ini dapat disebabkankarena adanya pengawasan yang benar dari orang tua dalam mengontrol makanan dan minuman yang akan dikonsumsi oleh anaknya.

Hasil uji statistik menunjukkan $p$ value $=0,000(p<0,05)$, yang berarti adanya hubungan bermakna antara mengonsumsi makanan selingan terhadap kejadian Early Childhood Caries (ECC). Responden cenderung mengonsumsi makanan selingan non kariogenik seperti kuaci, keju, popcorn tanpa gula, jagung, yogurt, teh tanpa gula 0-1 kali dalam sehari serta air putih $>3$ kali dalam sehari, tetapi ada beberapa responden yang mengonsumsi tahu, tempe, kentang serta buah $>3$ kali dalam sehari. Konsumsi makanan non kariogenik diketahui tidak berpotensi menyebabkan karies karena pada umumnya makanan non kariogenik terdiri dari makanan dengan kandungan serat dan protein yang baik untuk kesehatan gigi. ${ }^{26} \mathrm{Hal}$ ini sesuai dengan penelitian Systematic review yang menunjukkan bukti konsisten yang mendukung hubungan antara jumlah konsumsi makanan kariogenik dengan perkembangan karies dimana ditemukan kejadian karies lebih rendah apabila asupan makanan kariogenik berupa gula kurang dari $10 \%{ }^{27}$

Berdasarkan hasil penelitian diketahui bahwa responden dengan kriteria konsumsi makanan selingan baik juga dapat mengalami ECC dengan kategori tinggi, hal ini dapat disebabkan karena adanya faktor predisposisi karies lain yang mempengaruhi selain konsumsi makanan selingan kariogenik. Faktor keadaan dan pemeliharaan oral hygiene, morfologi gigi, susunan gigi, status ekonomi dan tingkat pendidikan merupakan faktor predisposisi lainnya. Kurangnya pemeliharaan kebersihan rongga mulut salah satunya cara menyikat gigi yang kurang tepat dan faktor morfologi gigi pit dan fisur pada gigi posterior sangat rentan terhadap teradinya karies. Hal ini disebabkan karena sisa-sisa makanan mudah menumpuk terutama pada gigi dengan permukaan pit dan fisurnya yang dalam. Tidak adanya kebiasaan berkumur setelah mengonsumsi makanan mempunyai risiko lebih tinggi terkena ECC karena berdasarkan penelitian yang dilakukan oleh Sicca et al (2016) berkumur (mouthrinse) merupakan salah satu metode untuk pencegahan karies pada anak. $28,29,30$ 
Berdasarkan hasil penelitian juga ditemukan responden dengan konsumsi makanan selingan yang buruk mengalami ECC dengan kategori tinggi, hal ini dapat terjadi karena tindakan sederhana yang belum dipahami oleh orang tua dan tidak diajarkan dengan benar kepada anak yaitu cara meyikat gigi yang benar serta waktu menyikat gigi yang tepat dan teratur yang harusnya diajarkan oleh orang tua kepada anak sejak usia dini. Hal ini didukung oleh hasil penelitian Budisuari et al (2010) yang meyatakan adanya hubungan yang bermakna antara pemeliharaan kesehatan gigi berupa menyikat gigi dengan kejadian karies dan penelitian Morita dan Yudhatama (2017) yang menjelaskan terdapat pengaruh antara pola asuh orang tua berupa diet makanan, kebiasaan minum susu sebelum tidur, kebiasaan menggosok gigi, dan kunjungan ke dokter gigi secara teratur terhadap kejadian ECC. ${ }^{25,31}$

\section{SIMPULAN}

Berdasarkan hasil penelitian mengenai hubungan mengonsumsi makanan selingan dengan Early Childhood Caries (ECC) pada anak usia 2-5 tahun di Kota Padang dapat ditarik kesimpulan bahwa terdapat hubungan antara mengonsumsi makanan selingan dengan Early Childhood Caries (ECC) pada anak usia 2-5 tahun di Kota Padang.

\section{KEPUSTAKAAN}

1. World Health Organization. Sugars and dental caries. WHO Departement of Nutrition for Health and Development, 2017; 17: 12.

2. Sun, H. B., Zhang, W., dan Zhou, X. B. Risk Factors associated with Early Childhood Caries. Chin J Dent Res, 2017; 20(2): 97-104.

3. Scheid, R. C., \& Weiss, G. Anatomi Gigi. Jakarta: EGC. 2014.

4. Garg, N., Garg, A., Text Book of Operative Dentistry Second ed. New Delhi: Jaypee Brothers Medical Publishers (P) Ltd. 2013.

5. Nakayama, N., \& Mori, M. Association Between Nocturnal Breastfeeding and Snacking Habits and the Risk of Early Childhood Caries in 18- to 23-Month-Old Japanese Children. J Epidemiol, 2015; 25(2): 142-147.

6. Adhani, R., Sari, N. N., \& Aspriyanto, D. Nursing mouth caries anak 2-5 tahun di Puskesmas Cempaka Banjarmasin. Jurnal PDGI, 2014, Vol. 63, No. 1, Jan-April.

7. Departemen Kesehatan Republik Indonesia. Riset Kesehatan Dasar (Riskesdas 2013). Jakarta. 2013.

8. Susi, S., et al., Analysis of Breastfeeding Pattern with Early Childhood Caries. World Journal of Dentistry, 2018; 9(3): 197-200.

9. McDonald, R. E., Avery, D. R., and Dean, J. A. Dentistry for the Child and Adolescent 8th ed. USA: Mosby. 2004.

10. Anil, S., Anand, P. S., Early Childhood Caries: Prevalence, Risk Factors, and Prevention. Frontiers in Pediatrics, 2017: 7(157).

11. Kartini, R. F., Primadona, S., Hubungan Bentuk, Rasa Makanan, dan Cara Penyajian dengan Sisa Makanan Selingan pada Pasien Anak di Rumah Sakit Angkatan Laut Dr. Ramelan Surabaya. Research Study, 2018, pp. 212-218. 
12. Johansson, I., et al., Snacking Habits and Caries in Young Children. Caries Res, 2010; 44: 421-430.

13. Mamengko, W., Kawengian, S. E., Siagian, K. V., Gambaran konsumsi jajanan dan status karies pada anak usia 3-5 tahun di Kelurahan Rinegetan Kecamatan Tondano Barat. Jurnal e-Gigi, 2016; 4(1): 1722.

14. Kartikasari, H. Y., Nuryanto, Hubungan kejadian karies gigi dengan konsumsi makanan kariogenik dan status gizi pada anak Sekolah Dasar (Studi pada anak kelas III dan IV SDN Kadipaten I dan II Bojonegoro). Journal of Nutrition College, 2014; 3(3): 414-421.

15. Febry, F., Kebiasaan jajan pada anak. Jurnal IImu Kesehatan Masyarakat, 2010; 1(2): 81-84.

16. Iftikhar, A., Zafar, M., Kalar, M. U., The relationship between snacking habits and dental caries in school children. International Journal of Collaborative Reasearch on Internal Medicine \& Public Health, 2012; 4(12): 1943-1951.

17. Arifin, Z., Gambaran Pola Makan Anak usia 3-5 tahun dengan Gizi Kurang di Pondok Bersalin Tri Sakti Balong Tani Kecamatan Jabon-Sidoarjo. Midwiferia , 2015; 1(1): 17-29.

18. Serrano, E., Powell, A., Healthy Eating for Children Ages 2 to 5 Years Old: A Guide for Parents and Caregivers. Virginia Cooperative Extension, Virginia Tech, Publication 348-150. 2013.

19. Winda, S. U., Gunawan, P., Wicaksono, D. A., Gambaran Karies Rampan pada Siswa Pendidikan Anak Usia Dini di Desa Pinelang II Indah. Jurnal e--Gigi (eG), 2015; 3(1): 175-181.

20. Hidayati, S., Utami, N. K., Amperawati, M. Indeks Def-t pada Anak Taman Kanak-kanak Sekota Banjarbaru Kalimantan Selatan. Jurnal Skala Kesehatan, 2014; 5(2): 1-7.

21. Phyo, A. Z., Chansatitporn, N., Narkswat, K., Oral Health Status and Oral Hygiene Habits Among Children Aged 12-13 years in Yangon, Myanmar. Southeast Asian J Trop Med Pub Health, 2013; 44(6): 1108-1114.

22. Widayati, N., Faktor yang Berhubungan dengan Karies Gigi pada Anak Usia 4-6 tahun . Jurnal Berkala Epidemiologi, 2014; 2(2): 196-205.

23. Aprillia, D. D., Khomsan, A., Konsumsi Air Putih, Status Gizi, dan Status Kesehatan Penghuni Panti Werda di Kabupaten Pacitan. J. Gizi Pangan, 2014; 9(3): 167-172.

24. Worotijan , I., Mintjelungan, C. N., Gunawan , P., Pengalaman Karies Gigi Serta Pola Makan dan Minum pada Anak Sekolah Dasar di Desa Kiawa Kecamatan Kawangkoan Utara. Jurnal e-Gigi, 2013; 1(1): 59-68.

25. Budisuari, M. A., Oktarina, Mikrajab, M. A., Hubungan Pola Makan dan Kebiasaan Menyikat Gigi dengan Kesehatan Gigi dan Mulut (Karies) di Indonesia. Buletin Penelitian Sistem Kesehatan, 2010; 13: 83-91.

26. Fejerskov, O., Kidd, E. Dental Caries and its Clinical Management Second ed. UK: Blackwell Munksgaard. 2008.

27. Moynihan, P. J., Kelly, S. A., Effect on Caries of Restricting Sugars Intake: Systematic Review to Inform WHO Guidelines. J Dent, 2014; 93: 3-18.

28. Bebe, Z. A., Susanto, H. S., \& Martini. Faktor Risiko Kejadian Karies Gigi pada Orang Dewasa Usia 20-39 tahun di Kelurahan Dadapsari, Kecamatan Semarang Utara, Kota Semarang. Jurnal Kesehatan Masyarakat, 2018; 6(1): 365-374. 
Fakultas Kedokteran Gigi Universitas Andalas

Jalan Perintis Kemerdekaan No. 77 Padang, Sumatera Barat

Web: adj.fkg.unand.ac.id Email: adj@dent.unand.ac.id

29. Sicca , C., et al., Prevention od Dental Caries: A Review of Effective Treatments. J clin Exp Dent, e604-e610. 2016.

30. Fatmawati, D. W. Hubungan Biofilm Streptococcus Mutans Terhadap Risiko Terjadinya Karies Gigi. Stogmatognatic (J.K.G Unej), 2011; 8(3): 127-130.

31. Sari, M., Yuyud, Y. Pola Asuh Orang Tua terhadap Kejadian ECC (Early Childhood Caries) pada Anak Usia 3-5 tahun di Kelurahan Purwosari Kota Surakarta. Universitas Muhammadiyah Magelang. 2017. 